\title{
Poetry and citizenship: \\ notes on slam poetry in São Paulo and Rio de Janeiro from 2016-2020
}

\author{
Daniela Silva de Freitas
}

\begin{abstract}
The dispute surrounding the meaning of citizenship and poetry has been one of the main concerns of slam poetry produced in São Paulo and Rio de Janeiro between 2016 and 2020. This text analyzes works by Carol Dall Farra, Lucas Afonso, Luiza Romão, Luz Ribeiro, Mel Duarte and Valentine and the context of their performance. It attempts to foreground the mutually constitutive relationship between poetry and citizenship in the slam produced in these cities during this period. This relationship is grounded both at the level of the word, in the topics brought to discussion by the poets, and at the level of performance, in the enactment and collective practice of slam poetry by members of the community; its organizers, poets, and audience members.
\end{abstract}

\section{Resumo}

A disputa acerca dos significados de poesia e cidadania é um dos eixos centrais do slam produzido em São Paulo e no Rio de Janeiro entre 2016 e 2020. Este texto analisa produções de Carol Dall Farra, Lucas Afonso, Luiza Romão, Luz Ribeiro, Mel Duarte e Valentine e seus contextos de performance para mostrar a relação mutuamente constitutiva entre poesia e cidadania presente no slam produzido nessas cidades durante esse período. Ao longo deste texto, veremos como essa relação se faz presente tanto no nível da palavra, dos assuntos postos em discussão pelos poetas, quanto no nível da performance, da prática coletiva do slam pelos membros de sua comunidade, seus organizadores, poetas e frequentadores. 
By the end of 2017 there were about forty-four poetry slams in the city of São Paulo. By the end of 2019 there were about two hundred and ten poetry slams in Brazil. The surge in numbers and the change in the scope of the research on the topic reflect the rising popularity of slam poetry across the country, with thousands of young people coming together to speak out loud the verses they have produced and to listen to the poetry composed by those around them. Unlike, for example, poetry slams in the USA (where this form of poetry was invented in the 1980s), which commonly take place in bars or cafés and one has to pay an admission fee to get in, poetry slams in Brazil take place in private spaces with open access to the public, or, after Slam da Guilhermina, in public areas, such as parks and squares. No entry or subscription fee is ever charged. One can always take part in the event for free, be it as a listener or a poet.

This particularity may be related to the fact that, from 2016 to 2020, citizenship, its negotiations and limitations, has been one of the most popular topics in poetry slams around the country. Of course, since the beginning of slam poetry in São Paulo in 2008, there have been poems about other topics, but from 2016 to 2020, citizenship has remained the topic bound to take the poet to the finals, both of a given poetry slam as well as those of state and national championships.

In addition to the discussion of issues of citizenship by poets and audience members, researchers and practitioners claim that democratic principles lie at the foundation of the idea of slam poetry. In her book The Cultural Politics of Slam Poetry, American poet and critic Susan Somers-Willett claims that:

the slam has thrived through the exercise of certain democratic ideals meant to contrast with exclusive academic conventions. Slams are rowdy yet welcoming events on the whole. From its beginnings, the poetry slam has adopted an opendoor policy: anyone can sign up to slam, and anyone in the audience is qualified to judge. [...] The poetry slam was founded on the tenets that the audience is not obligated to listen to the poet, that the poet should compel the audience to listen to him or her, that anyone may judge a competition, and that the competition should be open to all people and to all forms of poetry. Slam poetry is verse to which, at least theoretically, anyone can have access and whose worth anyone can determine. (Somers-Willett, 2009, p.5)

The accessibility of slam poetry questions traditional notions of what poetry is or should be, of who the poet is or can be, of the topics that can be discussed in poetry, of the mechanisms that determine poetry's worth, of the relationship between the poet and the 
audience, and of poetry's appropriate support/medium. In Jacques Rancière's (1999) terms, slam poetry provokes a disagreement that can potentially transform our society's regulated and policed ways of doing, ways of being, and ways of saying.

Like Somers-Willett, when describing the slam poetry movement, Brazilian slammer and critic Roberta Estrela D'Alva (2019, p.270-271) argues that "the idea of poetry slam is to democratize the access to poetry, handing it back to the people" ${ }^{1}$. She also writes that slam "has been used as a platform to create spaces where free poetic expression, free thinking and living together in diversity are experimented as practices of citizenship". She compares slams to agoras (the open space in ancient Greek cities), where current issues were debated. D'Alva (2014, p.111) also makes a point that poetry slams are communities, where practitioners "organize themselves collectively around a common interest, under a minimal set of norms and regulations" and where people celebrate the poet less than the community they belong to.

To British poet and academic Helen Gregory (2012, p.81), poetry slam is also a community, as well as "a movement, a philosophy, a form, a genre, a game, [...] an educational device, a career path and a gimmick". It is a competition, but it is also a for(u)m: a form, "a particular style of poetry (and performance)" and a forum, a place where people meet, speak and listen to each other.

In a round table at Feira Literária de Paraty (Flip) of 2020, Brazilian slammer Luz Ribeiro (2020) states that poetry slams and saraus are sites of democracy, where one has the chance to build a narrative from their own viewpoint. She says that if you go to a sarau and there are a hundred people there, you are going to have the chance to say your poetry once, while you will have to listen to the other ninety-nine people. The same principle determines the urgency of slam poetry. According to Ribeiro, if three minutes is all you have to address issues of racism, sexism or class, there is an urgency to your words. Therefore, saraus and poetry slams are poetic and political spaces where one can stand their ground. In slams, she says, she tells her own story, she maps out a territory of her own, with a body that is her territory, with a poetics that is not welcomed by big publishing houses, but is powerfully alive.

In this text I argue that the dispute surrounding the meaning of citizenship and poetry has constituted one of the main concerns of slam poetry produced in Rio de Janeiro and São Paulo between 2016 and 2020. In order to do so, I analyze the performances of poets

\footnotetext{
${ }^{1}$ All translations in this text are by the author.
} 
Lucas Afonso, Luiza Romão, Luz Ribeiro, and Mel Duarte from São Paulo, Carol Dall Farra and Valentine from Rio de Janeiro, as well as critical contributions from slammers themselves, including Roberta Estrela D'Alva and Tom Grito. While casting light on the work of these poets and the context of their production and reception, this text does not aim to be a comprehensive and detailed account of this scene, rather, it tries to render visible the intrinsic and constitutive relationship between slam poetry and citizenship.

The main source for the productions analyzed here - both poems and other texts and discourses produced by these poets - are videos, available on social media such as Facebook, Instagram, or YouTube. They are either recordings of live performances in poetry slams, interviews given by the poets, or round tables they have been part of. Although some of the poems have been published in books, their spoken and live versions recorded in video remain the most relevant medium for the analysis of slam poetry, since they retain some of the qualities of live performance, its effects of both sense and presence, its bodiliness, the reproduction of the voice and the body of the poet together with the verses, as well as the reaction of the audience/ interlocutors when listening to their words.

As Helen Gregory points out, slam is underscored by social interactions. A slam is an interactive event in which audience involvement is actively solicited. "The explicit attention that is paid to the performer/audience dynamic", she explains, "is something that sets slam apart not only from written poetry, but also from other forms of oral poetry". Audience members usually score the poems, but "they may also participate in other respects, helping organize, [...] or carry out a range of other tasks". The same is true for poets, "who are often involved in slam in more than one capacity, acting out performance, organizational, curatorial, [...] sound engineering, set design, and other roles" (2012, pp.82-83).

Gregory also comments that "the social interactions that take place in and around slams have more than merely practical value", which foregrounds the fact that "oral poems cannot be viewed as abstract texts, but must be understood as sited within concrete social interactions, which are themselves framed by the broader socio-historical context". Therefore, she says, when reflecting about slam poetry we should "ask not simply 'What does the text say?' but 'How is the text realized?'"'(2012, p.83). These are some of the aspects of slam poetry this text analyzes.

The issue of Brazilian politics, its characters - candidates, presidents, congressmen and the coverage their doings receive in mass media, as well as the impact their opinions and actions have upon the daily life of Brazilians has constituted the topic of some of Lucas Afonso's most popular poems. In Slam Resistência's final of 2016, Afonso presented a poem 
in which he organizes recent episodes of Brazilian politics, such as the amendment to the constitution that froze public investment for thirty years, including those in the field of public health and education; the coup d'etat that overthrew president Dilma; the protests of 2013; the military dictatorship and its remaining traces, subjects and actors that live on in contemporary Brazilian society. In this poem, Afonso prophetically demonstrates how all of these episodes are interconnected, having culminated, two years later, in the election of a former member of the military as president of Brazil².

Two years before the election, like Walter Benjamin's (1936) storyteller, the poet, tries to advise Brazilian trabalhadores - which in Brazilian Portuguese refers not to factory workers but to hard-working ordinary people - that those who sing the national anthem, wear the yellow jerseys of the Brazilian soccer team and beat pans are not the ones who wash those pans. He points out how those in favor of the coup, supporters of the former military dictatorship, are often resentful of public policies that have enabled real social change during the years of administration of the Brazilian Workers Party (PT), such as university quotas and public funding of university students or artists. Afonso tries to warn the listener not to score an own goal, since homages have been paid to torturers, such as General Ulstra, in whose honor Jair Bolsonaro casted his vote in Congress in favor of Roussef's impeachment.

The reference to an own goal has to do with the defeat the Brazilian soccer team suffered to Germany in the finals of the World Cup of 2014 in Maracanã, the humiliating $7 \times 1$, which is used by Afonso throughout the poem as an organizing metaphor to illustrate the many humiliations Brazilian trabalhadores have suffered since the hurtful match. The socalled mega-events of 2014-2016 - the World Cup of Soccer and the Rio de Janeiro Olympics - have provoked a lot of discontent in the Brazilian population, since large sums of public money were invested in areas that were not of primary public interest, which would not represent the change in infrastructure that the Brazilian capitals that hosted the events needed in the long term. Instead of building new hospitals, investing in public transportation or in education, much of the money, for instance, went into building large stadiums that would later be exploited by the private sector, with a massive increase in ticket prices. The bus fare increase was the final straw for the demonstrations of June 2013, which had a large impact on the rise of slam poetry in São Paulo.

The video I refer to shows Lucas Afonso performing his poetry in the middle of a circle of people gathered at Praça Roosevelt, in downtown São Paulo, the meeting point for

${ }^{2}$ Available at https://www.facebook.com/slamresistencia/videos/1212769128805804/ 
Slam Resistência. According to its organizers, Slam Resistência started as a series of poetic interventions that happened in meetings that took place in the same square during the demonstrations of 2013, called "Quintas de Resistência" (something like Thursdays to Resist). The meetings congregated a group of lawyers called the "Advogados Ativistas" (Activist Lawyers) and members of social movements and the civil society to discuss police brutality during the demonstrations and strategies to fight it. Since October 2014 (until March 2020), once a month, usually every first Monday of the month, Slam Resistência occupied the square. Its audience came from all around São Paulo to listen to the words of the poets. Audience members held their tongue and their breath at every poem spoken out loud, without the help of a microphone, in the middle of the noisy square.

It was in this square, in the 2016 finals of this poetry slam, that Afonso's poem was recorded and later uploaded to the Facebook page of Slam Resistência, where it was also able to reach a virtual audience. With Slam Resistência's practice of recording some of the poems from each edition and uploading them to their Facebook page, the popularity of slam poetry rose around the country. By means of watching, liking, commenting, and sharing the poems on Facebook, those who could not be present and enjoy the performance live at the square were also able to engage with the poem online. This virtual audience was also able to answer to Afonso's call to arms at the end of the poem:

\footnotetext{
Exalto a voz, solto meu verso na rua, Correndo o risco do após, sozinho em noite sem lua Sei que a maldade é veloz, o mal também não recua Mas não estamos a sós
} A luta continua. (Afonso, 2016)

Even though - as Afonso says in the poem, quoting a song sung by Elis Regina in the 1970s during the Brazilian military dictatorship - while the lights are red for those of us who are young and still live as our parents did, the potentiality of today's scenario is different. Favelas hold up high-caliber books against these political threats. Even if it means putting one's life at risk, the poet, as well as the other members of the community of that slam, occupy the square with their verses. The fight is on and they are in this together. Or so did his hopeful verses claim in 2016.

While, despite the fear for his life, Lucas Afonso seems to feel confident debating the current state of the nation, making jokes and treating the subject with a defiantly ironic stance, Luiza Romão claims she would like to write the word Brazil, to spell it out, to address it in poetry, but she cannot. Her failure in doing so has to do with the way the country has 
always treated women. The liaisons between coloniality, patriarchy, and nationalism are pointed out by her in the lines of "Relatos de um país fálico", accounts of a phallic country. The poem was also presented in an edition of Slam Resistência and its recording was posted on their Facebook page in March $2017^{3}$.

Romão starts by stuttering, looking for words, apparently trying to gather strength to say what she has to say. When she can finally speak, she says she would like to write the word Brazil. However, her pen, tired of always having to write the same old story, told her to stop and go back to the beginning of the sentence, the beginning of the book, the beginning of the story and to inquire where the name of the country came from. She goes back to Pedro Alvares Cabral's crosses and ships and remembers the name Brazil comes from the name of the tree: pau-brasil, brazilwood. The patriarchal wood, she says, white and hegemonic, which rightfully colonized wombs, destroyed virgin woods, was forcefully pushed into virgins. Colonization was rape, she claims.

For the sake of the word Brazil, she says, men have turned into animals, bandits into generals: Marechal Deodoro da Fonseca, Dom Pedro I, General Costa e Silva, Getúlio Vargas, Ernesto Geisel, Michel Temer, José Sarney. Their orders came from the head of an erected member. In the name of the country, men like them defend lowering the age of criminal responsibility, but fight abortion rights allegedly in defense of life.

Close to the end of her poem, Romão remembers an episode that was on the news at around the time of her performance. In May 2016, a 16-year-old girl from Rio de Janeiro had been drugged and collectively raped by thirty-three men, who recorded the crime and shared it online, where the images quickly spread. Romão writes: "É o pau-brasil, multiplicado 33 vezes e enfiado numa só garota" - the Brazilian wood, multiplied by thirty-three, shoved into only one girl.

She ends the poem by saying:

Eu olho pra caneta e eu tenho certeza

Eu não vou mais escrever o nome desse país

enquanto o estupro for prática cotidiana

e o nome de mulher a mãe gentil. (Romão, 2016)

As long as rape continues to be a daily practice, as long as rape culture remains, as long as women are trapped in the role of the kind and gentle mother from the Brazilian

${ }^{3}$ Available at https://www.facebook.com/slamresistencia/videos/1310311119051604/ 
national anthem, she will no longer write the name of the country. Those are the finishing lines of the poem. When she is done, the camera turns to the audience, to the many people watching her at the square. The public is in awe. There is a lot of noise and cheer. People clap, shout, and chant in support of her words. She gets a straight ten from all five judges and the video ends.

In "Slam Resistência: poesia, cidadania e insurgência", which I wrote in 2018, I analyzed the relationship between the poetry performed in Slam Resistência and the concept of insurgent citizenship, which I borrowed from James Holston (2008). Holston created the term to describe the change in the meaning and practice of citizenship he observed in a peripheral neighborhood in the city of São Paulo. In his research, he noticed that, around 1972, the people who lived in Jardim das Camélias used the word citizen in a derogatory manner and understood the law as an instrument for punishment, but thirtyone years later, people from this same neighborhood started using the law as an instrument for the protection of their rights. For Holston (2008), this attitude, the practice of insurgent citizenship, was especially evident at the micro-political level, in daily life interactions that would hardly take place at the center of the polis, but tended to happen in the private space of the oikos.

In my text, based on the analysis of four other poems performed at Slam Resistência, I argued that its practitioners - its poets, organizers and audience members - blurred the lines between the polis and the oikos, just like the genre of slam poetry blurred the limits between oral, written and visual modes. In a square downtown, in the center of the polis, the practitioners of Slam Resistência performed dramas that were at once private and public, personal and collective. The practice of insurgent citizenship happened in the center of the agora, took the square and broke the logics of the neoliberal city. It reclaimed the space of the city as a space of party and protest, appropriating, occupying, and re-signifying public space.

In opposition to the fortified enclaves - highly guarded condos, typical of the city of São Paulo after 1990 -, in opposition to the self-segregation of the elites and middle classes of the city that decided to seclude themselves from the diversity that makes up the city, the poetry slam occupied the square. It did so in defense of the right to the city of people who were usually estranged from it by two main limiting agents: the logics of the neoliberal city - that suffocates urbanity, divides and regulates the use of spaces, changing use value into exchange value - and the violence perpetrated not only by civilians but, mainly, by state 
representatives against a specific group of citizens, young people from peripheral areas of the city, often black and from lower classes.

According to Raquel Rolnik (2018), the emergence of young people from peripheral areas of the city to their new place as cultural actors in São Paulo, the new possibilities for their circulation and presence across the city, was one of the most significant changes in its recent history. The notion of circulation and presence as democratic participation is so central for the practitioners of this new kind of citizenship that the protests of June 2013 started precisely because of the price of the bus fare, raised by twenty cents. But it was not because of twenty cents, everyone said. It was for rights. It was for a life without turnstiles. After some demonstrations, all of these causes have proven to be interconnected. The influence of June 2013 was visible in Slam Resistência. By occupying the square (and the internet) and claiming rights, its poets, organizers, and audience members developed and adopted a new grammar - new forms, meanings and functions - to produce the city, to produce poetry and to produce life.

As a disruptive daily performance, the practice of citizenship was always bound to the level of words, discourse and disagreement. When Slam Resistência occupies the square, it re-signifies a space that is public, but, according to the logics of the neoliberal city, is not meant to be occupied by people or artists. Artists belong in concert halls, charging for people to go inside and watch them. Poets should be published and sell books if they want to communicate with their audience. Simple, pedagogical words on politics, spoken and listened to in the middle of a noisy square could hardly qualify as poetry. Besides, this different group of people, with their deviant use of standard language, their hairstyle, their skin color, their weird clothing, coming from distant peripheral neighborhoods and mingling at the square on Monday evenings could hardly qualify as poets. This was the disagreement operated by the poetry slam. The shock it provoked in the distribution of the sensible, in the distribution of places and roles, in the ways of saying, doing and being, constituted slam poetry as a mutual practice of art and citizenship (Rancière, 1999). It confounded the logic of who is or can be the poet, which subjects can be discussed, what poetry is, which spaces it can occupy, which functions it can serve, and how it can be accessed.

However, the limitations to the right to the city are imposed differently to each citizen, depending on the inscriptions one carries on their bodies, on their skins. There are those who cannot be present and circulate freely and safely around the city. There are those whose voices are not usually heard in the forum. Even in an environment such as Slam 
Resistência's, slammers felt there was a need for the creation of a separate space to welcome the voices of women. The first Slam das Minas - a poetry slam reserved for women slammers (where usually anyone except for cis men can perform) - was conceived by Tatiana Nascimento and founded by Tatiana Nascimento and Val Matos in Distrito Federal in 2015. In March 2016, Carol Peixoto, Luz Ribeiro, Mel Duarte, and Pam Araújo founded Slam das Minas SP. Today there are about eight Slam das Minas in different Brazilian states.

In the introduction to Querem nos calar: poemas para serem lidos em voz alta, an anthology of slam poetry written by Brazilian women and organized by slammer Mel Duarte, she comments on the relevance of this space:

The importance of the creation of a poetry slam with this configuration is historical, for the society we live in raises us to obey without questioning, to do the chores, to be subservient, but not to position ourselves, to be propositional, to go on stage and grab a microphone, and as soon as we do that, we are interrupted and undermined. So, we grow up carrying the burden of being silenced, but soon understand that, if there are no spaces for us to be appreciated, we should create them. (Duarte, 2019, p.11)

There is a video on YouTube of Mel Duarte performing her poem "Sobre empoderar", about empowerment, in the edition of April 3 ${ }^{\text {rd }}, 2017$ of Slam Resistência ${ }^{4}$. For some time now, empowerment has been a very popular word among young people in Brazil, mainly among young black women artists and thinkers. Closely connected with ideas of selfacceptance, self-affirmation, self-worth, self-acknowledgment and self-knowledge (Berth, 2018, p.14), it involves embracing one's roots and heritage and displaying it proudly, both in clothing and hairstyle as well as in attitude, in the adoption of a confident and defiant stance as a means to confront racism.

This is precisely what Mel Duarte does in her poem. She describes herself as a black poet of rare instinct, an athlete that exercises her words to go deep within. She claims she is not ambitious, that her dream is not of richness, that it usually takes her mother a month to make the money rich people spend on a night out and that is not what she dreams of. Her dream is to invade schools with black stories. She provokes the interlocutor, most likely a male fellow poet, and says that, if he needs more space, she will step aside, there is no need for dispute.

${ }^{4}$ Available at https://www.youtube.com/watch?v=18HfGOk3CPY 
She says she follows her intuition, because she often listens to voices whispering in her ears, trying to protect her from suspicious movements, quickly identified as dangerous, of men lurking around on the streets of the city. She says that now there is a new word: femicide, which since 2015 is judged by a legislation of its own in the Brazilian judicial system. Despite the fact that, at the time of her performance, more than four hundred women died monthly in Brazil, sixty percent of which were black women, there is a reactionary class of people who do not know how to use the word femicide. These were often the same ones who protested on Avenida Paulista, carrying signs, asking for a military intervention. The connections made by Duarte between conservative political demonstrations, femicide and women's empowerment expose how women are victims of violence, abuse and disrespect both in the symbolical level of discourse and representation and in the physical, concrete level of having the right to exist, to go around the city freely, to simply live their lives.

Duarte (2017) says society does not expect women to strike back, for during years we have been silenced, tied, abused, convinced we meant nothing, but now, she claims, "my generation will no longer be silent":

Pois durante anos fomos silenciadas, amarradas

Abusaram das nossas, as convenceram de que não eram nada

Só que a minha geração não fica mais calada,

Hoje minha boca é meu escudo e minha espada.

\section{$[\ldots]$}

Mas foi-se a época em que nos escondíamos

Pois hoje já posso avistar,

no horizonte um batalhão de mulheres em punga

Prontas para atacar!

Agora já é tarde, estamos espalhadas

Temos um legado a retomar

Por hora, $40 \%$ de mulheres,

Empoderadas

Mas essa estatística vai mudar

E quando menos esperarem,

Racistas, machistas - Vocês terão que se curvar! (Duarte, 2017) 
"Today my mouth is my shield and my sword", she declares. On the horizon ahead, she sees a battalion of women ready to attack. "Now it's too late", she claims, "we are everywhere. We have a legacy to take back". She ends her poem by telling racist and sexist men that "soon more women will join us" and when they least expect they will have to bow to our power.

In O que é o empoderamento?, Joice Berth (2018, p.16) explains that the idea of empowerment is not individual but collective, it is a "position of confrontation of oppression aiming at the elimination of the unfair situation and the balancing of existences in society". Berth (2018, p.40) writes that empowerment is not "to individually transcend certain barriers and to go on repeating the logics of oppression against other groups", but "to think of empowerment is to think of a set of antiracist, antisexist, anticapitalist strategies". She adds that:

individual and collective empowerment are two indissociable faces of the same process, $[\ldots]$ for an empowered collectivity can only be formed by individualities and subjectivities that are consciously active within empowering processes. [...] Empowerment is a resulting factor of the combination of individuals who reconstruct and deconstruct themselves in an ongoing process that culminates in the practical empowerment of the collectivity, which triggers the social transformations that will be enjoyed by everyone. (Berth, 2018, p.42-43)

After reading Duarte's poem we can see that this is exactly what empowerment means for the poet: not a solitary overcoming of barriers, but an individual and collective struggle that has the power to actively change society. It is not a path she treads alone, but a path tread by all women together. It is the reason why she created Slam das Minas SP together with her sisters, to give women the space they need, to build a poetry slam of their own, a space where their voice can be actively heard.

In Plantation Memories: Episodes of Everyday Racism, Grada Kilomba explains that there is a difference between speaking and being heard:

The act of speaking is like a negotiation between those who speak and those who listen. [...] Listening is, in this sense, the act of authorization toward the speaker. One can (only) speak when one's voice is listened to. Within this dialect, those who are listened to are those who 'belong'. And those who are not listened to become those who 'do not belong'. (Kilomba, 2010, p. 21-22) 
Finding authorization to speak is very rare for women in society. The realm of Brazilian literature and poetry is not a welcoming space for these voices either. Slam das Minas offers them a place to be listened to, a place to belong. In a video posted at the YouTube channel of Museu de Arte do Rio (MAR), Tom Grito, non-binary trans poet, one of the founders of Slam das Minas RJ, explains that:

Slam can render visible the voice of people who are usually not visible in society. People say "I am going to give voice...", but no one gives voice to anyone - this is something we are very critical about, because everyone has a voice of their own, but many times this voice is actually silenced. Somehow, within the three minutes people are watching and are going to stop to listen, slam gives the opportunity for the poet to speak about whatever the person wants to speak about. So, in Brazil, slam has this characteristic: it is very close to hip-hop, its poetry is laden with consciousness, with the idea of political participation. Slam das Minas came after mature pondering about the scene. As sexism is ingrained in our society, a lot of women rappers do not find space in rap, even though rap is a space of knowledge, of transmitting knowledge, it is still a very sexist space, so Slam das Minas comes out of this necessity. It is a more welcoming space, where you can speak about your pain without the presence of the oppressor there. This is the initial idea. And I think we could achieve it in some ways, because Slam das Minas RJ became a space for women, transvestites, trans men, and I think this space cannot be easily found either. [...] This can also be a social transformation, because many people who were invisible before start being visible. (Tom Grito, 2021)

Slam das Minas is a safe territory, where women can belong and be listened to as well as listen to each other. "Today, for me, my territory is this body", says Luz Ribeiro, in the round table at Flip in 2020 that I referred to in the beginning of this text. She says that being a peripheral 32-year-old black woman who is alive, who has a 33-year-old partner who is also alive, who has a 2-year-old child she can build narratives for - that is revolutionary. Being alive is revolutionary. Being invited to speak at an international literary fair is revolutionary. Just by existing and occupying those spaces she is fighting the necropolitics that produces and promotes her death and the death of her family.

On the YouTube channel of the Grand Poetry Slam/ International there is a recording of one of the poems Ribeiro performed at the World Cup of Slam Poetry of 2017, in Paris, which annually congregates national slam poetry champions from around the world ${ }^{5}$. The poem is called "Mulher de Palavra", which in Portuguese means both a woman made of words and a woman of her word. Another ambiguity in the poem is the use of the word

\footnotetext{
${ }^{5}$ Available at https://www.youtube.com/watch?v $=0$ ozgQtB8dnzM
} 
papel. She opens the poem saying she is a woman of papel, of paper, composed by cellulose and cellulite, but, as the poem unfolds, she turns to the discussion of the role of women role is another meaning for the word papel:

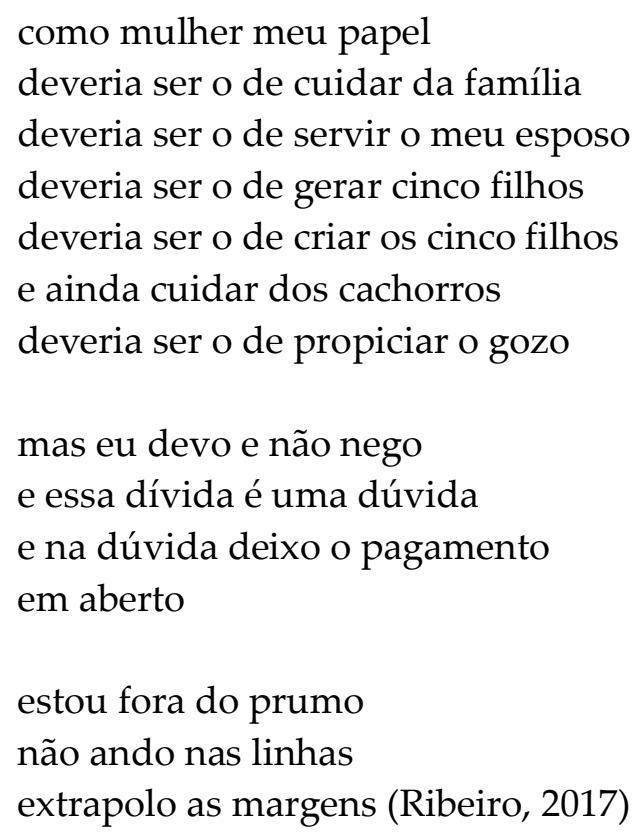

As a woman, she says, her role should be to take care of her family, to serve her spouse, to birth five children, to raise the five, to take care of the dogs, to give sexual pleasure. But this is a debt she owes and does not deny, but which she contests. And since there is room for contestation, she is leaving this debt pending, like herself, out of route, out of line, extrapolating the margins.

Her body, the one made of cellulose and cellulites, is soft. Her ample bosom used to be calm, but is now restless. Her stretch marks are maps that do not take anywhere. They are marks of a tired acceptance of one who has dared to fit into the unfitting: wearing size 38 , having straight hair, conforming to fashion, media, average models, but she has failed. She does not fit inside herself. Her world is vast, size 44. Her fist is iron. Her hair is up. People wished her to be hot. She is mild, but spicy. In three minutes, the length of a slam poem, she gets instantly cold, as the audience can see. She is just a line on the paper but she dares to outline poetry. She laughs, wishing for love. Her laughter is loose, her arms are loose, she lets the whole world escape, only that which suits her remains. Her legs are strong, but the ground keeps escaping her, because of her habit of flying with the wings given by poems. 
eu não estou nos livros

por isso escrevo histórias

$[\ldots]$

sou mulher de papel

no papel e fora dele

que oxalá me permita agora

ser uma mulher de palavra (Ribeiro, 2017)

She is not in books, Ribeiro declares, which is why she writes histórias (both histories and stories in Portuguese). She is a woman of papel, both in the paper and out of it, but may Oxalá allow her to be a woman of word, a woman of her word.

In the poem Ribeiro describes her body-territory, the one that is physical and abstract, the one that does not fit within standardized models, sizes, roles, books, narratives. That is why she is a woman of paper, a woman of word, whose role is to write new stories, to make history. She is a woman who wishes to live up to her word.

The subject of the body of the black mother and of her black daughter, their corporeal and philosophical existence, the limitations imposed by the color of the skin in intersection with their position as women and members of a lower economic class is the topic of "Na ponta do abismo", one of the poems that rendered Carol Dall Farra the title of champion of Slam das Minas RJ in the year of 2017. The recording of her performance can be watched on the YouTube channel of Slam das Minas RJ'.

The poem discusses the black mother, who walks on the edge of the abyss, bearing the weight of the universe upon her body. A body that shouts for help, that knew resistance before she knew existence. Subject to obstetric violence, a very common kind of violence perpetrated against black Brazilian women in hospitals, she birthed five children without any kind of labor pain relief. She has been unloved. Her chest beats with the pain of the death of one of her sons, shot by the police in the dark night just for being black, hence suspicious. But black women are strong, black women can handle it - this is the chorus both she and her daughter have heard throughout their lives, their fate written in the delays of history. Her black daughter, the poet, was born with her whole future already laid out in front of her: to inherit her place as a maid, to be hyper-sexualized, having lewd men staring

\footnotetext{
${ }^{6}$ Available at https://www.youtube.com/watch?v=DbQXy jicCXE
} 
at her since she was a child, to have fingers and guns pointed at her, all under the assumption that she can handle it:

Dedos te apontaram ontem e hoje o cano te aponta

Amanhã outro julgamento julgando que cê aguenta

Tua cabeça um reboliço

Teu corpo cumpriu caprichos

Tua mãe também passou por isso e todas da tua família

Tua vó bem que dizia:

- É uma praga feito sentença, eles dizem que a gente aguenta, mas eu vejo uma morte lenta

Tua vida nunca passou disso, nunca fugiu da sentença

Com as forças dos ancestrais internalizou que aguenta

Imaginou o chicote lento na vértebra de um branco

E viu que a força é um detalhe pra quem vive resistência (Dall Fara, 2017)

The poet tells the audience her grandmother used to say "It is a plague, like a life sentence. They say we can handle it, but I can see a slow death for us". The life of the poet was nothing other than that, she never escaped that sentence. With the strength of her ancestors, she internalized that she could handle it. She imagined the whip going down against the vertebra of a white man and realized that strength is a detail for those who live resistance.

Dall Farra's voice, her body and her flow are magnificent. She also gets a straight ten from the judges. Praça São Salvador, a square in Laranjeiras, in Rio de Janeiro, is crammed with people. The images captured in video show more than two hundred people listening to her silently, attentively. They cheer, whistle, shout and clap when she finishes her poem.

There is another video on the YouTube channel of Slam das Minas RJ of a poem by Valentine, a trans woman, who won the two-year commemorative edition of this poetry slam, which took place in Banca do André, in Cinelândia, in June 20197. In the poem Valentine compares herself to a doll, with no feelings. Her speech is programmed. When she is no longer of use, she is thrown away, with no ceremony or lament. Good to play with, easily dropped, she is not taken out of the house, but must be kept within four walls. She keeps secrets. She is lovely but she cannot be loved, for dolls do not feel love or fear. If she does not correspond to the pattern, she does not deserve love - that is what the owners of

\footnotetext{
${ }^{7}$ Available at https://www.youtube.com/watch?v=H5KWmNBigs0
} 
reason say. Her suffering is fun for them. In fact, none of this matters because dolls cannot feel depressed and she is like a doll.

After saying these words, the first half of her poem, Valentine bows. Since the beginning of the poem, Valentine has articulated words and moved her body in a way that imitated a wind-up doll. At this point she seems to wind down completely, which is why she bows, like a toy with no battery. The audience claps and cheers. Valentine drops the microphone she is using and starts shouting out loud to the audience members that she is not a doll. She feels fear, sorrow and loneliness. Audience members start cursing in surprise, as she tells them:

\author{
Mas não sou uma boneca \\ Me machuco, sinto dor e sangro \\ Dentro do meu peito bate um coração \\ Mas vocês comigo vão continuar brincando \\ E essa poesia não vai terminar com uma rima \\ Verão que mais difícil do que manter o clima \\ É ser um objeto que tem vida \\ E tentar manter a graça, a ternura e o que restou da alegria (Valentine, 2019)
}

She says she gets hurt, feels pain and bleeds. "There is a heart beating inside my chest", she claims and starts slapping against her chest, "yet you continue playing games with me". The camera shows people behind Valentine. Some of them are wide-eyed, staring. Others are smiling in sympathy and disbelief at the power of Valentine's performance. She says her poetry will not end with a rhyme. She says that, if there is anything harder than forecasting the climate - in Portuguese clima means both weather and ambiance -, it is being an object that is alive and struggles to keep on being funny, tender and somewhat joyful. She says she is not sure if a warning will do any good, but that she will repeat once again that she is not a doll, not an object, not a fetish, not a product. "I am a woman for you to respect and, above all", she shouts, again slapping against her chest, "I am a human being".

She ends the poem with a chorus she used to repeat at the end of all her poems at that time: "My name is Valentine, never Valentina. If you want to see me, you will find me at a poetry slam, never at a street corner." The corner is an allusion to prostitution, the most common occupation for trans women in Brazil, the place they are often restricted to occupy. Valentine's space is the poetry slam, the community to which she belongs as a poet. 
In the introduction to Performing Citizenship - Bodies, Agencies, Limitations, Paula Hildebrandt and Sibylle Peters (2019, p.1) state that "realities and concepts of citizenship have changed radically throughout history and will keep changing" and that today "new articulations of citizenship emerge". In citizens' and non-citizens' practices and struggles, often in conjunction with artistic practices, "new forms of togetherness, new strategies to claim rights and new civic roles are tested and rehearsed". In an attempt to approximate the concepts of citizenship and performance, Hildebrand and Peters (2019) outline three modes of the performativity of citizenship. First, they state citizenship is a subject position, a framework that not only gives meaning to our actions but primarily allows certain acts and actions to be real-that is, to constitute reality. Secondly, performing citizenship also means to claim and enact it outside of given structures. Even when they fail to claim, enact or presuppose a right that has yet to gain legal apparatus, individual citizens, citizen initiatives and movements all around the world persist in their trying, faking till they make it. To perform citizenship in this sense means to create a scene, to act as citizen in a way that potentially reinterprets the citizen as a role and as a subject position. Third,

habeas corpus - historically and biographically, the right to control one's own body is what initiates citizenship. The performance of this right, the steady reiteration of corresponding practices, effectively creates the body as 'my body', as something ' $\mathrm{I}$ ' own, a process that makes 'me' a citizen. It makes 'me' a citizen as 'my ownership' of 'my individual body' is dependent on being a member of other bodies, specific ones, which are dedicated to keeping the space open for individuals to perform their right. (Hildebrand and Peters, 2019, p.6)

By claiming ownership of their bodies and their meanings, by imagining collective bodies for themselves, by claiming and enacting rights that have yet to gain legal apparatus, faking till they make it, by creating a scene, the community of Slam das Minas performs poetry and performs citizenship. They imagine new forms of being together, of living together in the city.

Since March 2020, with the spread of the Covid-19 pandemic and the need for social distancing, poetry slams no longer occupy squares around the country. They can only occupy the internet with their words, their bodies and their voices. As a consequence, slam's language, topics, media and performer/audience dynamics have been transformed. Some tendencies have been interrupted, others have been intensified and new ones have arisen.

This text has tried to show how the slam poetry produced and performed in Rio de Janeiro and São Paulo from 2016 to 2020 interconnects and disputes the meanings of poetry 
and citizenship, shifting the terrains of Brazilian poetry and Brazilian literature, with black women poets occupying centerstage. For Jacques Rancière, this shift is precisely what characterizes political activity, for:

Political activity is whatever shifts a body from the place assigned to it or changes a place's destination. It makes visible what had no business being seen, and makes heard a discourse where once there was only place for noise; it makes understood as discourse what was once only heard as noise. (Rancière, 1999, p.30)

By listening to the poetic "noise" made by peripheral young people, by creating a space where the voice of those who have been silenced can be finally heard, slam communities politically redefine the meanings of poetry, messing with the distribution of the places and roles of both poetry and the poet. Apparently aware of the "intrinsic relationship between performativity and citizenship, who owe to each other much of their corresponding world-making powers" (Hildebrand and Peters, 2019, p.7), slam practitioners imagine and enact a new world.

\section{Bibliography}

Benjamin, W. (1936) The Storyteller: Reflections on the Works of Nikolai Leskov. Available at: https://arl.human.cornell.edu/linked\%20docs/Walter\%20Benjamin\%20Storyteller.pdf (Accessed: 30 April 2021)

Berth, J. (2018) O que é o empoderamento?. Belo Horizonte: Letramento.

D’Alva, R. E. (2014) Teatro hip-hop: a performance poética do ator-MC. São Paulo: Perspectiva.

D'Alva, R. E. 'SLAM: voz de levante'. Rebento, (10), p. 268-286. Available at: http://www.periodicos.ia.unesp.br/index.php/rebento/article/view/360 (Accessed: 30 April 2021)

Duarte, M. (org.) (2019) Querem nos calar: poemas para serem lidos em voz alta. São Paulo: Planeta do Brasil.

Freitas, D. S. de. (2020) 'Slam Resistência: poesia, cidadania e insurgência'. Estudos De Literatura Brasileira Contemporânea, (59), p.1-15. Available at: https://periodicos.unb.br/index.php/estudos/article/view/29317 (Accessed: 30 April 2021)

Flip - Festa Literária Internacional de Paraty (2020) mesa 12 I Zé Kleber: Slam, com Nathalia Leal e Luz Ribeiro - áudio original e libras. Available at: https://www.youtube.com/watch?v=kZigv-QoCdk (Accessed: 30 April 2021)

GICA TV (2017) Slam Resistência Abril - Mel Duarte. Available at: https://www.youtube.com/watch?v=18HfGOk3CPY (Accessed: 30 April 2021)

Grand Poetry Slam/ International (2018) Luz Ribeiro (Brésil), "Mulher De Palavra". Available at: https://www.youtube.com/watch?v=OzgQtB8dnzM (Accessed: 30 April 2021) 
Gregory, H. (2012) 'Poetry Performances on the Page and Stage: Insights from Slam', in Gingell, S. and Roy, W. (eds.) Listening up, writing down, and looking beyond: interfaces of the oral, written and visual. Waterloo: Wilfrid Laurier University Press, pp.77-95.

Hildebrand, P. and Peters, S. (2019) “Introduction”. in Hildebrand, P. et al (eds.) Performing Citizenship: Bodies, Agencies, Limitations. Hamburg: Palgrave Macmillan, pp.1-13.

Holston, J. (2008) Insurgent citizenship: disjunctions of democracy and modernity in Brazil. Princeton and Woodstock: Princeton University Press.

Kilomba, G. (2010) Plantation Memories: Episodes of Everyday Racism. Münster: UNRAST-Verlag.

Rancière, J. (1999) Disagreement: politics and philosophy. Minneapolis and London: University of Minnesota Press.

Rolnik, R. (2017) Territórios em conflito: São Paulo, espaço, história e política. São Paulo: Três Estrelas.

Slam das Minas RJ (2019) SLAM DAS MINAS RJ - 2 ANOS - Valentine. Available at: https://www.youtube.com/watch?v=H5KWmNBigs0 (Accessed: 30 April 2021)

Slam das Minas RJ (2017) SLAM DAS MINAS RJ FINAL 2017 - Carol Dall Farras. Available at: https://www.youtube.com/watch?v=DbQXy jcCXE (Accessed: 30 April 2021)

Slam Resistência. (2016) Lucas Afonso, representante do Brasil na França no ano passado e, neste ano, foi finalista no nosso Slam. Available at: https://www.facebook.com/slamresistencia/videos/1212769128805804/ (Accessed: 30 April 2021)

Slam Resistência. (2017) Luiza Romão, slammer das antigas... Available at: https://www.facebook.com/slamresistencia/videos/1310311119051604/ (Accessed: 30 April 2021)

Somers-Willett, S. B. A. (2009) The cultural politics of slam poetry: race, identity, and the performance of popular verse in America. Ann Arbor: The University of Michigan Press. 